\title{
PERKEMBANGAN TANGGUNG JAWAB PEMEGANG SAHAM PERSEOAN TERBATAS DALAM UNDANG-UNDANG NASIONAL MENGGANTIKAN HUKUM WARISAN KOLONIAL
}

\author{
Acep Rohendi \\ Universitas BSI Bandung \\ Email : arohendi1209@gmail.com
}

\begin{abstract}
Law No. 40 of 2007 concerning Limited Liability Companies (UUPT) revokes Law Number 1 Year 1995 concerning Limited Liability Companies (UUPTL). This UUPTL replaces the provisions of a limited liability company inherited from the Dutch East Indies contained in the Commercial Code (KUHD) stipulated in the Third Section concerning Limited Liability Companies starting from Article 36 to Article 56 KUHD. The shareholders who are regulated in the UUPTL and the KHUD are not personally responsible for the agreements made on behalf of the Company and are also not responsible for the Company's losses in excess of the value of the shares they have. The KUHD also states that shareholders are not responsible for more than the full amount of their shares. Its development after being determined by the Company Law in 2007, the responsibility of the shareholders is not absolutely valid. The liability is unlimited and personal responsibility is fully imposed on the shareholders of the limited company in the 2007 Company Law. If the shareholders of a limited company violate or fulfill the elements stipulated in Article 3 paragraph (2) of the Company Law, or known as the Piercing The Corporate Veil principle (disclosure of the company's veil). This development is a sanction to shareholders of a limited liability company, which in the previous provision was unknown.
\end{abstract}

Keywords : Responsibility of shareholders, limited liability companies the Piercing The Corporate Veil,

\section{PENDAHULUAN}

Tujuan pembangunan hukum nasional dilakukan diantaranya dengan membentuk peraturan perundang-undangan yang menampung aspirasi masyarakatnya, berintikan keadilan dan kebenaran yang mengabdi kepada kepentingan rakyat dan bangsa yang tentunya dibuat dan dilaksanakan dalam bingkai Negara Kesatuan Republik Indonesia ${ }^{1}$. Perseroan Terbatas (selanjutnya dalam makalah ini disebut perseroan) sebagai salah satu pilar pembangunan perekonomian nasional perlu diberikan landasan hukum yang kuat

\footnotetext{
${ }^{1}$ Sujud Margono, Hukum Perusahaan Indonesia: Catatan atas UU Perseroan Terbatas, Novindo Pustaka Mandiri, Jakarta, 2008, hlm. 22.
} 
untuk memacu pembangunan nasional yang disusun sebagai usaha bersama berdasarkan asas kekeluargaan, dengan tetap memunculkan prinsip-prinsip keadilan dalam berusaha. Sejalan dengan kebijakan dasar tersebut, Pemerintah telah mengundangkan UU No.40 Tahun 2007 Tentang Perseroan Terbatas (selanjutnya dalam makalah ini disebut UUPT) menggantikan UU No.1 Tahun 1995 Tentang Perseroan Terbatas (selanjutnya dalam makalah ini disebut UUPTL) yang sebelumnya menggantikan ketentuan Bagian Ketiga Tentang Perseroan Terbatas yang diatur dalam Pasal 36 sampai dengan Pasal 56 Kitab Undang-Undang Hukum Dagang (selanjutnya dalam makalah ini disebut KUHD).

Baik UUPTL maupun UUPT memulai Ketentuan Umum dengan beberapa pengertian penting yang berkaitan dengan perseroan. Hal ini berlainan dengan ketentuan Perseroan dalam KUHD yang tidak mengaturnya ${ }^{2}$. Perbedaan pengertian pada kedua undang-undang tersebut yaitu pada UUPT disebutkan bahwa Perseroan adalah badan hukum yang merupakan persekutuan modal, didirikan berdasarkan perjanjian, melakukan kegiatan usaha dengan modal dasar yang seluruhnya terbagi dalam saham dan memenuhi persyaratan yang ditetapkan dalam Undang- Undang ini serta peraturan pelaksanaannya ${ }^{3}$, sedangkan pada UUPTL disebutkan bahwa Perseroan adalah badan hukum yang didirikan berdasarkan perjanjian, melakukan kegiatan usaha dengan modal dasar yang seluruhnya terbagi dalam saham dan memenuhi persyaratan yang ditetapkan dalam Undang- Undang ini serta peraturan pelaksanaannya ${ }^{4}$. Pada UUPT terdapat penambahan kata yang menegaskan bahwa Perseroan adalah badan hukum yang merupakan persekutuan modal, sedangkan pada UUPTL hanya disebutkan bahwa Perseroan adalah badan hukum saja.

Perseroan merupakan subjek hukum yang berstatus badan hukum dengan ciri utama adanya pemisahan antara harta kekayaan badan hukum dan pribadi para pemegang saham. Dengan demikian, para pemegang saham tidak bertanggung jawab secara pribadi atas perikatan yang dibuat atas nama Perseroan dan juga tidak bertanggung jawab atas kerugian Perseroan melebihi nilai saham yang dimasukannya ${ }^{5}$. Pada KUHD juga disebutkan bahwa para pemegang saham tidak bertanggung jawab untuk lebih daripada jumlah penuh andilnya ${ }^{6}$.

\footnotetext{
${ }^{2}$ Man S. Sastrawidjaja \& Rai Mantili, Perseroan Terbatas Menurut Tiga Undang-Undang (WvK, UU No.1 Tahun 1995, UU No.40 tahun 2007) Jilid 1, Alumni, Bandung, 2008, hlm. 18.

${ }^{3}$ Pasal 1 angka 1 UUPT.

${ }^{4}$ Pasal 1 angka 1 UUPTL.

5 Pasal 3 ayat (1) UUPT.

${ }^{6}$ Pasal 40 ayat (2) KUHD.
} 
Namun tanggung jawab tersebut tidak berlaku mutlak. Para pemegang saham dapat bertanggung jawab tidak terbatas atau bertanggung jawab secara pribadi untuk sepenuhnya apabila memenuhi ketentuan yang terdapat dalam Pasal 3 ayat (2) UUPT yang dikenal dengan prinsip Piercing The Corporate Veil atau penyingkapan tabir perusahaan sebagai sanksi kepada pemegang saham yang sebelumnya tidak diatur dalam ketentuan KUHD ${ }^{7}$.

Dari latar belakang yang telah diuraikan di atas, maka permasalahan dalam penelitian ini adalah sebagai berikut:

1. Bagaimana pertanggungjawaban pemegang saham dalam perseroan terbatas?

2. Bagaimana penerapan prinsip Piercing The Corporate Veil menurut UUPT?

\section{METODOLOGI PENELITIAN}

Metode penelitian untuk menjawab permasalahan menggunakan Penelitian Hukum, dengan pendekatan yang digunakan dalam penelitian hukum ini adalah penelitian hukum normatif, yang merupakan penelitian hukum yang doktrinal biasanya hanya dipergunakan sumber-sumber data sekunder saja, seperti peraturan-peraturan perundangundangan, dan pendapat-pendapat para ahli hukum terkemuka sedangkan analisa yang dilakukan berupa analisa normatif-kualitatif / yuridis normatif.

\section{PEMBAHASAN}

\subsection{Pertanggungjawaban Pemegang Saham Dalam Perseroan Terbatas}

Perseroan (disebut juga Naamloze Vennootschaap (NV) dalam bahasa Belanda), merupakan suatu persekutuan untuk menjalankan usaha yang memiliki modal terdiri dari saham-saham, yang pemiliknya memiliki bagian sebanyak saham yang dimilikinya. Karena modalnya terdiri dari saham-saham yang dapat diperjualbelikan, perubahan kepemilikan perusahaan dapat dilakukan tanpa perlu membubarkan perusahaan ${ }^{8}$. Di Indonesia, pengaturan tentang Perseroan diatur dalam Undang- Undang No.40 Tahun 2007 Tentang Perseroan Terbatas (UUPT), menggantikan Undang- undang No.1 Tahun 1995 (UUPTL) yang sebelumnya mencabut ketentuan pasal 36- pasal 56 KUHD tentang Perseroan Terbatas dan berikut segala perubahan terakhir dengan Undang- Undang No.4

\footnotetext{
${ }^{7}$ Man S. Sastrawidjaja \& Rai Mantili, Op. Cit., hlm. 29-30.

${ }^{8}$ Munir Fuadi, Perseroan Terbatas- Paradigma Baru, Citra Aditya Bakti, Bandung, 2003, hlm. 3.
} 
Tahun 1971 dan Stb. No.569 jo. No.717 Tahun 1939 Tentang Ordonansi Maskapai Andil Indonesia.

Dalam Pasal 1 angka 1 UUPT disebutkan bahwa Perseroan adalah badan hukum yang merupakan persekutuan modal, didirikan berdasarkan perjanjian, melakukan kegiatan usaha dengan modal dasar yang seluruhnya terbagi dalam saham dan memenuhi persyaratan yang ditetapkan dalam Undang- Undang ini serta peraturan pelaksanaannya. Dari pengertian tersebut, diketahui bahwa unsur- unsur dari Perseroan adalah sebagai berikut:

a. badan hukum,

b. persekutuan modal,

c. didirikan berdasarkan perjanjian,

d. melakukan kegiatan usaha,

e. modal dasar terbagi dalam saham, dan

f. memenuhi persyaratan yang ditetapkan dalam UUPT.

Terdapat perbedaan pengertian antara UUPT dan UUPTL. Pada UUPT terdapat penambahan kata yang menegaskan bahwa Perseroan adalah badan hukum yang merupakan persekutuan modal, sedangkan pada UUPTL hanya disebutkan bahwa Perseroan adalah badan hukum saja.

Perseroan merupakan legal entity, yaitu badan hukum mandiri yang memiliki sifat dan ciri kualitas yang berbeda dari bentuk usaha lain, yang dikenal dengan karakteristik suatu Perseroan, yaitu':

1) sebagai asosiasi modal,

2) kekayaan dan utang Perseroan adalah terpisah dari kekayaan dan utang pemegang saham,

3) pemegang saham memiliki tanggung jawab terbatas (limited liability), yaitu bertanggung jawab hanya pada apa yang disetorkan dan tidak bertanggung jawab secara pribadi atas perikatan yang dibuat atas nama PT dan atas kerugian Perseroan melebihi saham yang dimilikinya.

4) adanya pemisahan fungsi antara pemegang saham dengan pengurus atau Direksi,

5) memiliki Dewan Komisaris yang berfungsi sebagai pengawas.

Dimaksud dengan persekutuan modal adalah persekutuan yang mengutamakan terkumpulnya modal sebanyak- banyaknya dengan cara menjual saham. Sebagai kebalikan

${ }^{9}$ I. G. Ray Widjaya, Hukum Perusahaan, Megapoin, Jakarta, 2007, hlm. 143. 
dari persekutuan modal adalah persekutuan orang, yaitu persekutuan yang mengutamakan kualitas sekutunya. Oleh karena itu, kerja sama para anggota dari persekutuan orang sangat erat ${ }^{10}$.

Modal suatu Perseroan sebagaimana persekutuan modal terdiri atas tiga macam, yaitu modal dasar, modal yang ditempatkan dan modal yang disetorkan. Adapun yang dibagi atas saham adalah modal dasar yang disebutkan dalam anggaran dasar. Modal ditempatkan adalah modal yang dijanjikan oleh para pendiri, sedangkan modal yang disetorkan adalah modal yang sudah konkret ada dalam Perseroan ${ }^{11}$. Modal dasar perseroan paling sedikit Rp.50.000.000,00 (lima puluh juta rupiah) ${ }^{12}$, sedangkan modal yang ditempatkan paling sedikit $25 \%$ (dua puluh lima persen) dari modal dasar dan harus disetor penuh ${ }^{13}$. Saham merupakan tanda penyertaan modal seseorang atau pihak (badan usaha) dalam suatu perseroan. Dengan menyertakan modal tersebut, maka pihak tersebut memiliki klaim atas pendapatan perseroan, klaim atas asset perseroan, dan berhak hadir dalam Rapat Umum Pemegang Saham (selanjutnya dalam makalah ini disebut RUPS) ${ }^{14}$.

Saham merupakan benda bergerak dan memberikan hak kepemilikan kepada pemegangnya ${ }^{15}$. Sehingga setiap pemegang saham berhak mengajukan gugatan kepada perseroan ke pengadilan negeri, tempat dimana perseron itu berkedudukan. Hal ini terjadi jika pemegang saham merasa dirugikan oleh perseroan.

Setiap pemegang saham berhak meminta kepada perseroan agar sahamnya dibeli dengan harga yang wajar jika pemegang saham yang bersangkutan tidak menyetujui tindakan perseroan yang dinilai merugikan pemegang saham itu sendiri maupun perseroan, yang berupa ${ }^{16}$ :

a) perubahan anggaran dasar,

b) penjualan, penjaminan, pertukaran sebagian besar atau seluruh kekayaan perseroan, atau

c) penggabungan, peleburan, atau pengambilalihan perseroan.

Jika saham yang diminta untuk dibeli melebihi batas ketentuan pembelian kembali saham oleh perseroan, perseroan wajib mengusahakan agar sisa saham dibeli oleh pihak

\footnotetext{
${ }^{10}$ Man S. Sastrawidjaja \& Rai Mantili, Op. Cit., hlm. 15.

${ }^{11}$ Sujud Margono, Op. Cit., hlm. 41.

12 Pasal 32 ayat (1) UUPT.

13 Pasal 33 ayat (1) UUPT.

${ }^{14}$ Frans Satrio Wicaksono, Tanggung Jawab Pemegang Saham,Direksi, dan Komisaris Perseroan Terbatas $(P T)$, Visimedia, 2009 ,hlm. 59.

15 Ibid., hlm. 17.

${ }^{16}$ Ibid., hlm. 18.
} 
lain. Pemegang saham diberi bukti pemilikan saham untuk saham yang dimilikinya. Setiap saham memberikan kepada pemiliknya hak yang tidak dapat dibagi kepada orang lain. Namun jika terdapat satu lembar saham dimiliki oleh beberapa orang, hak yang timbul dari saham tersebut hanya dapat digunakan dengan cara menunjuk satu orang wakil ${ }^{17}$.

Pendirian Perseroan diatur dalam Pasal 7 sampai dengan Pasal 30 UUPT dengan tahap-tahap sebagai berikut:

1. Pembuatan Akta Pendirian

Dalam Pasal 7 ayat (1) UUPT disebutkan bahwa Perseroan didirikan oleh dua orang atau lebih dengan akta notaris yang dibuat dalam bahasa Indonesia. Untuk mendirikan Perseroan, harus membuat akta notaris yang disebut dengan akta pendirian yang di dalamnya memuat anggaran dasar dan keterangan lain yang berkaitan dengan pendirian perseroan ${ }^{18}$ yang sekurang-kurangnya memuat ${ }^{19}$ :

a. Nama lengkap, tempat dan tanggal lahir, pekerjaan, tempat tinggal dan kewarganegaraan pendiri perseroan atau nama, tempat kedudukan, dan alamat lengkap serta nomor dan tanggal Keputusan Menteri Hukum dan HAM mengenai pengesahan badan hukum dar pendiri perseroan,

b. Susunan, nama lengkap, tempat dan tanggal lahir, pekerjaan, tempat tinggal dan kewarganegaraan Direksi dan Dewan Komisaris yang pertama kali diangkat,

c. Nama pemegang saham yang telah mengambil bagian saham, rincian jumlah saham, dan nilai nominal saham yang telah ditempatkan dan disetor pada saat pendirian.

2. Pengesahan Menteri Hukum dan HAM

Akta pendirian yang telah dibuat harus mendapatkan pengesahan dari Menteri Hukum dan HAM untuk mendapatkan status sebagai badan hukum. Mekanisme pengesahan tersebut terdapat pada Pasal 9 sampai dengan Pasal 11 UUPT.

3. Pendaftaran dan Pengumuman

Setelah mendapat pengesahan, peraturan dalam UUPTL menyebutkan bahwa akta pendirian disertai Surat Keputusan pengesahan dari Menteri Hukum dan HAM harus didaftarkan dalam Daftar Perusahaan ke Kantor Pendaftaran Perusahaan oleh Direksi ${ }^{20}$, tetapi selanjutnya sesuai UUPT, Daftar Perseroan diselenggarakan oleh

${ }^{17}$ Ibid., hlm.16.

${ }^{18}$ Pasal 8 ayat (1) UUPT.

${ }^{19}$ Pasal 8 ayat (2) UUPT.

${ }^{20}$ Pasal 21 UUPTL 
Menteri Hukum dan HAM $^{21}$. Sedangkan dalam UUPTL, pengumuman dalam Berita Negara Republik Indonesia (BNRI) merupakan kewajiban Direksi Perseroan yang bersangkutan ${ }^{22}$, tetapi dalam UUPT diubah menjadi kewenangan/ kewajiban Menteri Hukum dan $\mathrm{HAM}^{23}$.

Konsekuensi dari kemandirian perseroan yaitu segala risiko yang timbul dari perbuatan perseroan menjadi tanggung jawab perseroan itu sendiri. Selain itu, perseroan harus mempunyai harta kekayaan sendiri terlepas dari harta pribadi para pemegang saham dan atau orang-orang yang menjalankan perseroan tersebut. Sehingga apabila dalam melakukan kegiatannya terjadi kerugian atau mendapatkan keuntungan, maka perbuatan tersebut menjadi beban dan atau keuntungan perseroan itu sendiri. Pengurusan pada perseroan harus dilakukan oleh suatu organ. Dalam Pasal 1 angka 2 UUPT disebutkan bahwa Organ Perseroan adalah RUPS, Direksi dan Dewan Komisaris.

Mengenai RUPS, Pasal 1 angka 3 UUPTL menyebutkan sebagai organ perseroan yang memegang kekuasaan tertinggi dalam perseroan dan memegang segala wewenang yang tidak diserahkan kepada Direksi atau Komisaris, sedangkan dalam UUPT tidak disebutkan RUPS sebagai organ perseroan yang memegang kekuasaan tertinggi. Dengan demikian, UUPT melakukan perubahan mengenai kedudukan RUPS tersebut. Perubahan tersebut disebabkan adanya perubahan pandangan yang berkembang mengenai kedudukan RUPS. Menurut pandangan klasik, ketika organ, yaitu Direksi, Komisaris dan RUPS kedudukannya berjenjang dengan RUPS sebagai pemegang kekuasaan tertinggi. Menurut teori institusional sebagai pandangan mutakhir, kedudukan ketiga organ tersebut tidak berjenjang, kedudukan setiap organ sederajat dan tidak ada satu organ yang lebih tinggi dari organ yang lain (Dengan demikian, UUPT mengubah pandangan dari UUPTL yang menganut teori klasik menjadi teori institusional) ${ }^{24}$.

Direksi adalah organ perseroan yang bertanggung jawab penuh atas pengurusan perseroan untuk kepentingan dan tujuan perseroan, serta mewakili perseroan, baik di dalam maupun diluar pengadilan, sesuai dengan ketentuan anggaran dasar. Dewan Komisaris merupakan organ perseroan yang bertugas melakukan pengawasan secara

\footnotetext{
${ }^{21}$ Pasal 29 ayat (1) UUPT

${ }^{22}$ Pasal 22 ayat (2) UUPTL.

${ }^{23}$ Pasal 30 UUPT.

${ }^{24}$ Man S. Sastrawidjaja \& Rai Mantili, Op. Cit., hlm. 19-20.
} 
umum dan atau khusus serta memberikan nasehat kepada direksi dalam menjalankan $\operatorname{perseroan}^{25}$.

Perseroan dapat dibubarkan dengan alasan sebagai berikut, seperti dalam ketentuan Pasal 142 UUPT:

1. berdasarkan keputusan RUPS,

2. karena jangka waktu berdirinya,

3. berdasarkan penetapan pengadilan,

4. dengan dicabutnya kepailitan berdasarkan putusan Pengadilan Niaga yang telah mempunyai kekuatan hukum tetap, harta pailit perseroan tidak cukup untuk membayar biaya kepailitan,

5. karena harta pailit perseroan yang telah dinyatakan pailit berada dalam keadaan insolvensi sebagaimana diatur dalam undang-undang tentang Kepailitan dan Penundaan Kewajiban Pembayaran Utang, atau

6. karena dicabutnya izin usaha perseroan sehingga mewajibkan perseroan melakukan likuidasi sesuai dengan ketentuan peraturan perundang-undangan.

Secara hukum, tanggung jawab suatu perusahaan dapat dibedakan ke dalam dua kelompok, yaitu:

1. Tanggung jawab hukum dari perusahaan yang tidak berbentuk badan hukum.

Apabila suatu prusahaan tidak berbentuk badan hukum, misalnya perusahaan dalam bentuk firma, maka tidak ada harta yang terpisah yang merupakan harta perseroan tersebut. Akan tetapi, yang ada hanyalah harta dari pemilik perusahannya ${ }^{26}$. Oleh karena itu, secara hukum tidak ada pemisahan antara tanggung jawab perusahaan dengan tanggung jawab pribadi pemilik perusahaan.

Dengan demikian, jika suatu kegiatan yang dilakukan oleh atau atas nama perusahaan dan terjadi kerugian bagi pihak ketiga, maka pihak ketiga tersebut dapat meminta pemilik perusahaan untuk bertanggung jawab secara hukum, termasuk meminta agar harta benda pribadi dari pemilik perusahaan tersebut disita dan dilelang. Hal tersebut merupakan konsekuensi dari ketentuan hukum yang menyatakan bahwa seluruh harta

\footnotetext{
${ }^{25}$ Frans Satrio Wicaksono, Op. Cit., hlm. 6.

${ }^{26}$ Munir Fuady, Doktrin-Doktrin Modern Dalam Corporate Law dan Eksistensinya Dalam Hukum Indonesia, Citra Aditya Bakti, Bandung, 2002, hlm. 2.
} 
benda sesorang menjadi tanggungan bagi utang-utangnya sebagaimana diatur dalam Pasal 1131 KUHPerdata $^{27}$.

2. Tanggung jawab hukum dari perusahaan yang berbentuk badan hukum.

Bagi perusahaan yang berbentuk badan hukum seperti perseroan terbatas, koperasi, dan lain-lain, maka secara hukum pada prinsipnya harta bendanya terpisah dari harta benda pemiliknya. Oleh karena itu, tanggung jawab secara hukum juga dipisahkan dari harta benda pribadi pemilik perusahaan yang berbentuk badan hukum tersebut ${ }^{28}$. Jadi, misalnya suatu perseroan melakukan suatu perbuatan dengan pihak lain, maka yang bertanggung jawab adalah perseroan tersebut dan tanggung jawabnya sebatas pada harta benda yang dimiliki oleh perseroan tersebut. Harta benda pribadi pemilik perseroan atau pemegang sahamnya tidak dapat disita atau digugat untu dibebankan tanggung jawab perseroan tersebut. Hal tersebut dikarenakankan adanya tanggung jawab terbatas dari pemilik saham.

Mengenai istilah perseroan terbatas, kata terbatas disebabkan berlakunya tanggung jawab pemegang saham dari suatu perseroan. Dengan demikian, yang terbatas bukan besarnya modal atau kegiatan usahanya, tetapi menunjukan adanya tanggung jawab terbatas dari pemegang saham yang merupakan ciri khas dari suatu perseroan ${ }^{29}$.

\subsection{Penerapan Prinsip Piercing The Corporate Veil menurut UUPT}

Pada dasarnya pertanggungjawaban pemegang saham dalam Perseroan adalah terbatas, namun pertanggungjawaban tersebut tidak berlaku mutlak. Hal tersebut timbul terutama jika sebuah badan hukum dijadikan sebagai vihicle untuk maksud- maksud yang menyimpang dari norma hukum. Oleh karena itu, muncul prinsip Piercing The Corporate Veil yang secara sederhana dapat dikatakan bahwa tanggung jawab pemegang saham dalam hal tertentu dapat menjadi tak terbatas ${ }^{30}$.

Prinsip Piercing The Corporate Veil tidak diatur dalam KUHD, namun diatur dalam UUPTL dan UUPT. Prinsip tersebut mengajarkan bahwa suatu badan hukum hanya bertanggung jawab secara hukum hanya terbatas pada harta badan hukum tersebut, tetapi

\footnotetext{
${ }^{27}$ Idem.

${ }^{28}$ Ibid., hlm. 3.

${ }^{29}$ Man S. Sastrawidjaja \& Rai Mantili, Op. Cit., hlm. 28.

${ }^{30}$ Tri Widiyono, Direksi Perseroan Terbatas (Bank dan Perseroan) Keberadaan, Tugas, Wewenang dan Tanggung Jawab Berdasarkan Doktrin Hukum dan UUPT, Ghalia Indonesia, Jakarta, 2005, hlm. 30.
} 
dalam hal-hal tertentu batas tanggung jawab tersebut dapat ditembus (piercing) ${ }^{31}$. Prinsip tersebut sebelumnya hanya dikenal dan berkembang dalam konsep hukum perseroan di negara-negara yang menganut sistem hukum Anglo Saxon atau Common Law System, yang kemudian diadopsi ke dalam sistem hukum perseroan Indonesia yang dikenal dengan nama penyingkapan tabir perusahaan. Tabir yang disingkap maksudnya adalah diterobosnya pertanggungjawaban terbatas dari pemegang saham yang telah ditetapkan dalam pasal 3 ayat (1) UUPT $^{32}$.

Prinsip tersebut bertujuan untuk menghindari hal-hal yang tidak adil terutama bagi pihak luar Perseroan dari tindakan sewenang-wenang atau tidak layak yang dilakukan atas nama perseroan, baik yang timbul dari suatu transaksi dengan pihak ketiga, maupun yang timbul dari perbuatan melawan hukum.

Kriteria dasar dan universal agar prinsip tersebut secara hukum dapat dijatuhkan adalah sebagai berikut ${ }^{33}$ :

1. terjadinya penipuan,

2. didapatkan suatu ketidakadilan,

3. terjadinya suatu penindasan (oppression),

4. tidak memenuhi unsur hukum (illegality),

5. dominasi pemegang saham yang berlebihan, atau

6. perusahaan merupakan alter ego dari pemegang saham mayoritasnya.

Dengan demikian, prinsip piercing the corporate veil pada hakekatnya merupakan prinsip yang memindahkan tanggung jawab dari perusahaan kepada pemegang saham, direksi atau dewan komisaris, dan biasanya prinsip tersebut baru diterapkan jika ada klaim dari pihak ketiga kepada perseroan ${ }^{34}$.

Suatu perseroan berbeda dengan suatu persekutuan yang bukan merupakan legal entity dan tidak terpisah dari para sekutu yang menjadi anggota dari persekutuan tersebut. Sebagai suatu legal entity yang tepisah dari para pemegang sahamnya, perseroan dalam melakukan fungsi hukumnya bukan bertindak sebagai kuasa dari para pemegang sahamnya, tetapi bertindak untuk dan atas nama perseroan itu sendiri. Para pemegang saham bukan merupakan pihak dari perjanjian yang dibuat oleh perseroan dengan pihak

\footnotetext{
${ }^{31}$ Munir Fuady, 2003, Op. Cit., hlm. 61.

${ }^{32}$ Rachmadi Usman, Dimensi Hukum Perusahaan Perseroan Terbatas, Alumni, Bandung, 2004, hlm. 152.

${ }^{33}$ Munir Fuady, 2002, Op. Cit., hlm. 10.

${ }^{34}$ Munir Fuadi, 2003, Op. Cit., hlm .87.
} 
lain. Oleh karena itu, pemegang saham juga tidak berhak memaksa pihak lain untuk melaksanakan kewajibannya yang ditentukan dalam perjanjian tersebut ${ }^{35}$.

Dengan demikian, antara pemegang saham dan perseroan merupakan pihak yang terpisah. Para pemegang saham tidak dapat dituntut untuk melunasi utang perseroan, walaupun pemegang saham tersebut adalah pemilik perseroan. Pemegang saham hanya bertanggung jawab terbatas pada saham yang dimilikinya. Dengan kata lain, pemegang saham tidak berkewajiban untuk melunasi utang perseroan walaupun hasil penjualan harta kekayaan perseroan masih belum mencukupi. Demikian pula pihak ketiga tidak dapat menuntut para pemegang saham untuk memenuhi kewajiban perseroan apabila harta kekayaan perseroan tidak mencukupi.

Pada suatu badan hukum dikenal prinsip kemandirian badan hukum yang artinya setiap perbuatan hukum yang dilakukan oleh suatu badan hukum, hanya badan hukum sendiri yang bertangung jawab. Para pemegang saham tidak bertanggung jawab kecuali sebatas saham yang dimasukkannya ${ }^{36}$.

Dalam KUHD prinsip tersebut bersifat mutlak. Pasal 40 ayat (2) KUHD menyebutkan bahwa para persero atau pemegang saham/andil tidak bertanggung jawab melebihi jumlah penuh saham/andilnya. Namun akan timbul permasalahan jika pendirian perseroan sebenarnya merupakan kedok usaha yang dipakai pemegang saham untuk menghindari kerugian yang timbul akibat keterlibatannya dalam perseroan.

Oleh karena itu, dalam pengaturan perseroan selanjutnya, baik dalam UUPTL yang kemudian diganti menjadi UUPT yang menegaskan bahwa perseroan sebagai suatu persekutuan modal, berkembang prinsip baru mengenai tanggung jawab pemegang saham. Prinsip tersebut dikenal sebagai prinsip Piercing The Corporate Veil atau penyingkapan tabir perusahaan.

Dalam hukum Indonesia, prinsip kemandirian badan hukum dari suatu perseroan diakui secara tegas dalam UUPT yang menyebutkan bahwa pemegang saham perseroan tidak bertanggung jawab secara pribadi atas perikatan yang dibuat atas nama perseroan dan tidak bertanggung jawab atas kerugian perseroan melebihi saham yang dimilikinya ${ }^{37}$. Hal tersebut berarti harta kekayaan pribadi para pemegang saham tidak ikut dipertanggungjawabkan sebagai tanggungan perikatan yang dilakukan oleh badan hukum yang bersangkutan.

\footnotetext{
${ }^{35}$ Rachmadi Usman, Op. Cit., hlm. 147-148.

${ }^{36}$ Ibid., hlm. 149.

${ }^{37}$ Pasal 3 ayat (1) UUPT.
} 
Keterpisahan tanggung jawab hukum antara perseroan dengan pribadi pemegang saham tersebut lebih mempertegas ciri dari suatu perseroan terbatas, yaitu pemegang saham bertanggung jawab secara terbatas yang hanya bertanggung jawab sebesar nilai saham yang dimilikinya dan tidak meliputi harta kekayaan pribadinya.

Akan tetapi ketentuan tersebut tidak berlaku mutlak, sebab terdapat banyak pengecualian dari ketentuan tersebut. Pengecualian tersebut mengisyaratkan bahwa UUPT mengakui adanya prinsip Piercing The Corporate Veil. Pengecualian yang diatur dalam UUPT yang khususnya dibebankan pada pemegang saham adalah sebagai berikut:

1. Pasal 3 ayat (2) UUPT.

Dalam ketentuan tersebut, UUPT mengintrodusir tanggung jawab pemegang saham terbatas dalam hal-hal sebagai berikut ${ }^{38}$ :

a. Persyaratan perseroan sebagai badan hukum belum atau tidak terpenuhi. Dalam hal ini, pihak pemegang saham sebagai pendiri perseroan yang bertanggung jawab secara mutlak sampai dengan disahkannya badan hukum perseroan oleh Menteri Hukum dan HAM. Setelah pengesahan, tanggung jawab tersebut beralih pada pihak direksi sampai dengan pendaftaran dan pengumuman. Setelah pendaftaran dan pengumuman, maka yang bertanggung jawab hanyalah perseroan yang bersangkutan kecuali terdapat alasan untuk diterapkannya prinsip Piercing The Corporate Veil karena alasan-alasan lain.

b. Pemegang saham baik langsung maupun tidak langsung dengan itikad buruk memanfaatkan perseroan untuk kepentingan pribadi.

c. Pemegang saham telibat dalam perbuatan melawan hukum yang dilakukan oleh perseroan.

d. Pemegang saham baik langsung maupun tidak langsung secara melawan hukum menggunakan kekayaan perseroan, yang mengakibatkan kekayaan perseroan menjadi tidak cukup untuk melunasi utang perseroan.

Perbuatan-perbuatan diatas (kecuali hurup a), pada dasarnya merupakn perbuatan melawan hukum. Dengan adanya akibat hukum demikian, dituntut pemegang saham hati-hati dan selalu beritikad baik dalam menjalankan peran dan kedudukannya sebagai pemilik perseroan. Khusus untuk akibat hukum dalam hurup a, yaitu apabila persyaratan perseroan sebagai badan hukum belum atau tidak terpenuhi, sebenarnya merupakan kewenangan dari pengurus atau pendiri perseroan (yang

${ }^{38}$ Munir Fuady, 2002, Op. Cit., hlm. 19. 
biasanya diberikan kuasa kepada notaris untuk mengurusnya). Jadi, bukan kesalahan pemegang saham kecuali yang bersangkutan sebagai pendiri atau pengurus perseroan tersebut ${ }^{39}$.

Dalam hal terjadi pembauran antara kekayaan perseroan dengan kekayaan pribadi, maka pihak pemegang saham bertanggung jawab secara pribadi, yaitu apabila terbukti bahwa pembauran tersebut dijadikan alasan untuk mendirikan perseroan sebagai alat yang dipergunakan pemegang saham untuk memenuhi tujuan pribadinya.

2. Pasal 7 ayat (6) UUPT.

Pada suatu perseroan, pemegang saham paling sedikit harus berjumlah dua orang. Jumlah tersebut sampai kapanpun harus dipertahankan oleh perseroan, kecuali untuk perseroan dalam hal sebagai berikut ${ }^{40}$ :

a. Persero yang seluruh sahamnya dimiliki oleh negara, atau

b. Perseroan yang mengelola bursa efek, lembaga kliring dan penjaminan, lembaga penyimpanan dan pentelesaian, dan lembaga lain yang diatur dalam UndangUndang No.8 Tahun 1995 Tentang Pasar Modal.

Jika perseroan karena hal apapun akhirnya hanya mempunyai satu orang pemegang saham, maka dalam jangka waktu enam bulan terhitung sejak saat pemegang saham tersebut hanya bejumlah satu orang, pemegang saham tersebut wajib mengalihkan sebagian sahamnya kepada pihak lain atau perseroan mengeluarkan saham baru kepada pihak lain ${ }^{41}$. Dalam hal ini UUPT tidak mengatur batas minimal untuk pengalihan saham. Jadi, satu saham saja yang dialihkan kepada pihak lain sudah cukup.

Namun jika jangka waktu enam bulan tersebut telah dilampaui, pemegang saham masih berjumlah satu oang, maka berlaku prinsip Piercing The Corporate Veil. Artinya, yang bertanggung jawab terhadap pihak ketiga bukan hanya perseroan, tetapi juga pribadi pemegang saham perseroan tersebut, dan atas pemohonan pihak yang berkepentingan, pengadilan negeri dapat membubarkan perseroan tersebut ${ }^{42}$ karena alasan adanya cacat hukum dalam akta pendirian ${ }^{43}$.

\footnotetext{
${ }^{39}$ Man S. Sastrawidjja dan Rai Mantili, Op. Ci.t, hlm.30.

${ }^{40}$ Pasal 7 ayat (7) UUPT.

${ }^{41}$ Pasal 7 ayat (5) UUPT.

${ }^{42}$ Pasal 7 ayat (6) UUPT.

${ }^{43}$ Pasal 146 ayat (1) hurup b UUPT.
} 


\section{PENUTU}

Berdasarkan hasil pembahasan terhadap perkembangan tanggung jawab pemegang saham pada perseoan terbatas sebagai suatu persekutuan modal, maka dapat disimpulkan:

1. Pada perseroan, pemegang saham memiliki tanggung jawab terbatas hanya sebesar saham yang dimilikinya yang diatur dalam Pasal 3 ayat (1) UUPT yang sebelumnya menggantikan Pasal 3 ayat (1) UUPTL dan Pasal 40 ayat (2) KUHD. Hal ini sesuai dengan pengertian kata terbatas dalam perseroan terbatas yang menunjukan adanya tanggung jawab terbatas dari pemegang saham yang merupakan ciri khas dari suatu perseroan.

2. Prinsip Piercing The Corporate Veil sebagai perkembangan tanggung jawab pemegang saham dalam perseroan, mengatur tentang pertanggungjawaban pemegang saham secara pribadi atas perikatan yang dibuat atas nama perseroan dan atas kerugian perseroan melebihi saham yang dimilikinya apabila pemegang saham melakukan perbuatan yang diatur dalam Pasal 3 ayat (2) dan Pasal 7 ayat (6) UUPT.

\section{DAFTAR PUSTAKA}

\section{$\underline{\text { Buku }}$}

Frans Satrio Wicaksono, 2009, Tanggung Jawab Pemegang Saham, Direksi, dan Komisaris Perseroan Terbatas (PT), Visimedia, Jakarta.

I. G. Ray Widjaya, 2007, Hukum Perusahaan, Megapoin, Jakarta.

Man S. Sastrawidjaja \& Rai Mantili, 2008, Perseroan Terbatas Menurut Tiga UndangUndang (WvK, UU No.1 Tahun 1995, UU No.40 tahun 2007) Jilid 1, Alumni, Bandung.

Munir Fuady, 2002, Doktrin-Doktrin Modern Dalam Corporate Law dan Eksistensinya Dalam Hukum Indonesia, Citra Aditya Bakti, Bandung.

Munir Fuady, 2003, Perseroan Terbatas- Paradigma Baru, Citra Aditya Bakti, Bandung.

Rachmadi Usman, 2004, Dimensi Hukum Perusahaan Perseroan Terbatas, Alumni, Bandung.

Sujud Margono, 2008, Hukum Perusahaan Indonesia: Catatan atas UU Perseroan Terbatas, Novindo Pustaka Mandiri, Jakarta. 
Tri Widiyono, 2005, Direksi Perseroan Terbatas (Bank dan Perseroan) Keberadaan, Tugas, Wewenang dan Tanggung Jawab Berdasarkan Doktrin Hukum dan UUPT, Ghalia Indonesia, Jakarta.

Peraturan Perundang-undangan :

Kitab Undang-Undang Hukum Perdata.

Kitab Undang-Undang Hukum Dagang.

Undang-Undang No.1 Tahun 1995 Tentang Perseroan Terbatas.

Undang-Undang No.40 Tahun 2007 Tentang Perseroan Terbatas. 